\title{
ECF Bleaching with Molybdenum Activated Acid Peroxide and Its Impact on Eucalyptus Pulp Properties and Effluent Quality
}

\author{
Marco Antônio Bandeira Azevedo ${ }^{1}$, Vânya Márcia Duarte Pasa ${ }^{1}$, Hannu Hämäläinen², \\ Ann Honor Mounteer ${ }^{3}$, Rubens Chaves de Oliveira $^{3}$, Jorge Luiz Colodette ${ }^{3^{*}}$ \\ ${ }^{1}$ Departament of Chemical, Universidade Federal de Minas Gerais, Belo Horizonte, Brazil; ${ }^{2}$ Kemira Oy, Vaasa, Finland;
${ }^{3}$ Departament of Forest Engineering, Universidade Federal de Viçosa, Viçosa, Brazil.
E-mail: colodett@ufv.br
}

Received December $17^{\text {th }}, 2010$; revised January $31^{\text {st }}, 2011$; accepted February $1^{\text {st }}, 2011$.

\begin{abstract}
Acid hydrogen peroxide catalyzed with molybdenum (PMo stage) is effective to decrease pulp kappa number and potentially minimize chlorine dioxide demand in subsequent ECF bleaching. This study aimed at developing cost-effective methods for applying PMo as the first stage bleaching for eucalyptus kraft pulp and evaluating their impact on pulp properties and effluent quality in relation to current ECF bleaching techniques. The PMo $(E P) D P$ and $A / P M o(E P) D P$ sequences proved to be most cost-effective for PMo stage application. The pulp properties and effluent quality derived from bleaching with these two sequences were compared with those of the conventional bleaching with the $D_{H T}(E P) D P$ sequence. The PMo(EP)DP sequence produced pulp of refinability and physical properties similar to that of the reference but the $A / P M o(E P) D P$ one resulted in pulp of $20 \%$ lower refinability and $10 \%$ lower tearing strength. Untreated effluents of the PMo(EP)DP and A/PMo(EP)DP sequences presented similar COD, but lower AOX and color than the $D_{H \mathrm{~T}}(E P) D P$ effluents. None of the effluents exhibited acute toxicity. The effluents from the PMo(EP)DP sequence showed much lower $B O D$ and $B O D / C O D$ ratio than that of the $A / P M O(E P) D P$ one. All effluents were readily treated in bench-scale reactors, and achieved COD removal efficiencies of greater than $70 \%$.
\end{abstract}

Keywords: Molybdenum, Bleaching, Eucalyptus, Kraft Qulp, Effluent, Pulp Quality

\section{Introduction}

There has been a growing demand for light Elemental Chlorine Free (light-ECF) pulps, particularly in Europe, in order to replace the very expensive Totally Chlorine Free (TCF) ones. There is no clear definition for the so-called light-ECF pulps, but the market tends to accept under this denomination the bleached pulps that contain less than 50-60 $\mathrm{g} \mathrm{Cl}^{-} /$adt pulp of organically bound chlorine substance $(\mathrm{OX})$, as measured by a standard test method such as SCAN-CM 52:94, PTS-RH 012/90, ISO 11480 , etc [1]. Such a low bound chlorine target requires that ECF bleaching be implemented under unusual operational conditions, i.e., with very low chlorine dioxide charges [2]. Many bleaching alternatives have been evaluated to minimize chlorine dioxide use for eucalyptus kraft pulps, one of them being the so-called molybdenum activated hydrogen peroxide stage (PMo).

The use of siliconmolybdate activated peroxide blea- ching has been very thoroughly investigated for bleaching or Scandinavian kraft pulp [3]. The great advantage of this stage in relation to other stages run under acidic conditions is the minimum formation of oxalic acid that can cause scaling in thee bleach plant. Oxalic acid is produced through acid hydrolysis that occurs when an acid stage (e.g. ozone and chlorine dioxide) is used to remove pulp hexenuronic acids [4]. In relation to potential molybdenum residuals in the bleaching filtrate [3] have shown that the amount is sufficiently low in order to cause significant damages to the effluent treatment system. On the other hand, no effect in the chemical recovery system was seen due to the low amount of molybdenum used in the reaction. In addition, part of the filtrate can be cycled back to the PMo stage thus recovering significant amounts of the molybdenum catalyst [5].

The acid peroxide bleaching activated with heavy metal salts was investigated firstly by [6] and subsequently by [7] who evaluated its reactivity towards several 
lignin models compounds. The main conclusions were that molybdenum salts are more effective than the tungsten ones in the $\mathrm{pH}$ range of 2-5. Furthermore, the lignin models containing a free phenolic hydroxyl group were more reactive than those without these groups. The delignification action during the molybdenum catalyzed acid peroxide bleaching (PMo stage) was ascribed to the ability of the molybdate to form together with the hydrogen peroxide the diperoxi-molybdenum complex. Several different molybdenum-containing species can serve as catalysts, including sodium and ammonium molybdate, molybdenum trioxide, siliconmolybdate, etc.

Reference [1] has studied the use sodium and ammonium molybdate activated peroxide bleaching for eucalyptus pulps and determined that optimal conditions for such treatment include temperature of $90-95^{\circ} \mathrm{C}$ for 2 hours, $\mathrm{pH} 3.5$ and molybdenum and hydrogen peroxide charges of $0.1 \mathrm{~kg} / \mathrm{t}$ and $5 \mathrm{~kg} / \mathrm{t}$, respectively. They also concluded that the kappa number reduction in the PMo stage can reach 7 units and occurs mainly through hexenuronic acids removal (HexA's) from the pulp. [8] Evaluated the sodium molybdate activated peroxide stage for bleaching of an oxygen delignified eucalyptus kraft pulp (high HexA content) to $90 \%$ ISO brightness in short ECF (Elemental Chlorine Free) and TCF (Totally Chlorine Free) sequences: $\mathrm{PMoDP}, \mathrm{PMoD} / \mathrm{P}, \mathrm{PMoD}(\mathrm{PO}), \mathrm{PmoQ}$ (PO) and XPMoQ (PO. Among the ECF alternatives, the three-stage PMoDP sequence proved attractive particularly in regard to effluent quality. However, a four stage sequence-XPMoQ(PO)-was required to achieve full brightness using the TCF technology.

It is apparent that the PMo stage is an alternative for bleaching eucalyptus pulps, particularly with the focus of shortening the current bleach plants and recycling part of the bleach plant filtrate. However, many questions still remain in regard to PMo stage application for eucalyptus pulps. For example, what types of sequences are more suited for such stage? Would the PMo stage work well in any type of eucalyptus pulp or only on those rich in hexenuronic acids? What is the impact of such stage on eucalyptus pulp properties and effluent quality and treatability? Some of these questions are addressed in this study that embraces the following objectives: (1) evaluating PMo stage in various sequences for bleaching eucalyptus pulp of two different origins (high/low HexA); (2) determining the impact of using the PMo stage on bleaching effluent load and treatability and on pulp refinability and physical-mechanical properties.

\section{Experimental}

\subsection{Bleaching Experiments}

Two eucalyptus pulp samples were collected in the last washer after the oxygen delignification stage of two different bleach plants. The main specifications of these two pulp samples are presented in Table 1. These samples were designated as easy-and difficult-to-bleach pulps on the basis of their chemical requirements to achieve $90 \%$ ISO brightness with the D(EP)DP sequence. Except when otherwise stated, pro analysis reagents were used throughout the study. The $\left(\mathrm{NH}_{4}\right)_{6} \mathrm{Mo}_{7} \mathrm{O}_{24} \cdot 4 \mathrm{H}_{2} \mathrm{O}$ salt was used as the source of molybdenum catalyst and was purchased from the Aldrich Chemical company.

The molybdenum activated acid peroxide stage was optimized taking into account the temperature (85 and $\left.95^{\circ} \mathrm{C}\right)$, the end $\mathrm{pH}(3.0$ and 4.5$)$ and the molybdenum dose $(0.10,0.15$ and $0.25 \mathrm{~kg} /$ odt pulp). The reaction time $(2 \mathrm{~h})$, reaction consistency $(10 \%)$ and hydrogen peroxide dose $(5 \mathrm{~kg} / \mathrm{odt}$ pulp) were kept constant throughout the study.

The PMo stage optimized according to the conditions above was applied to the PMo(EP)DP, A/PMo(EP)DP, $\mathrm{PMo} / \mathrm{Q}(\mathrm{PO})$ and $\mathrm{PMoZ} / \mathrm{ED}$ bleaching sequences. The $\mathrm{D}(\mathrm{EP}) \mathrm{DP}, \mathrm{D}_{\mathrm{HT}}(\mathrm{EP}) \mathrm{DP}, \mathrm{A} / \mathrm{D}(\mathrm{EP}) \mathrm{DP}, \mathrm{D} / \mathrm{Q}(\mathrm{PO})$ and $\mathrm{Z} / \mathrm{ED}$ $P$ sequences were used as references. Oxidant charges were optimized in the $\mathrm{D}_{1}$ and (PO) stages in order to achieve $90 \%$ ISO final brightness.

Hot chlorine dioxide $\left(\mathrm{D}_{\mathrm{HT}}\right)$, pressurize peroxide $(\mathrm{PO})$, hot acid hydrolysis (A) and ozone $(\mathrm{Z})$ bleaching stages were carried out in a model Mark $\mathrm{V}$ mixer/reactor (Quantum Technologies Inc.). Conventional alkaline extraction (E), extraction with peroxide (EP), peroxide $(\mathrm{P})$, chlorine dioxide (D) and molybdenum activated acid peroxide bleaching (PMo) and chelation $(\mathrm{Q})$ stages were carried out in polyethylene bags. The main reaction conditions used are presented in Table 2. After each bleaching stage, run in duplicate, the samples were washed with excess distilled water, except in those cases where the washing step was deliberately omitted. Reagent doses are expressed in kg per oven dried ton of pulp (odt). Concentrations of oxidants and residuals were measured according to [9].

Pulp kappa number, viscosity, brightness and brightness stability values were measured according to TAPPI standard procedures. Hexenuronic acids were measured by UV after their conversion into furoic acid using acid hydrolysis with formic acid [10]. Pulp OX and filtrate AOX values were measured in an absorbable organic halogen analyzer (ECS 1600-Euroglas), according to SCAN procedure. Filtrate total organic carbon (TOC) values were measured directly in a Shimadizu model 5000A TOC analyzer. Bleached pulp samples were refined in a PFI mill at 0, 1000, 2000 and 3000 revolutions and tested for physical-mechanical properties according to Tappi standard procedures. Bleaching chemical costs 
Table 1. Specifications of the two oxygen delignified eucalyptus pulp samples.

\begin{tabular}{ccc}
\hline Parameters & Difficult-to-bleach Pulp & Easy-to-bleach Pulp \\
\hline Brightness, \%ISO & 44.3 & 54.3 \\
Viscosity, mPa.s & 30.2 & 23.8 \\
Kappa number & 10.9 & 11.9 \\
HexA, mmol/kg & 42.4 & 63.3 \\
\hline
\end{tabular}

Table 2. General bleaching conditions.

\begin{tabular}{|c|c|c|c|c|c|c|c|c|c|c|}
\hline \multirow{2}{*}{$\begin{array}{l}\text { BLEACHING } \\
\text { CONDITIONS }\end{array}$} & \multicolumn{10}{|c|}{ BLEACHING STAGE } \\
\hline & $\mathrm{D}_{0}$ & $\mathrm{~A} / \mathrm{D}$ & $\mathrm{D}_{\mathrm{HT}}$ & $\mathrm{D}_{\mathrm{HT}} / \mathrm{Q}$ & $\mathrm{Z} / \mathrm{E}$ & (EP) & $\mathrm{D}_{1}$ & (PO) & $\mathrm{P}$ & PMo \\
\hline Consistency, $\%$ & 10 & $11 / 10$ & 10 & $10 / 9$ & $40 / 10$ & 10 & 10 & 10 & 10 & 10 \\
\hline Temp, ${ }^{\circ} \mathrm{C}$ & 60 & $95 / 90$ & 95 & $95 / 90$ & $50 / 60$ & 80 & 80 & 90 & 80 & $85 ; 95$ \\
\hline Time, min & 30 & $110 / 10$ & 120 & $120 / 30$ & $1 / 30$ & 90 & 120 & 120 & 120 & 120 \\
\hline Pressure, $\mathrm{kPa}$ & - & - & - & - & - & - & - & 500 & - & - \\
\hline Kappa Factor (KF) & 0.16 & $0 / 0.16$ & 0.16 & $0.2 / 0$ & - & - & - & - & - & - \\
\hline End $\mathrm{pH}$ & 2.7 & $2.7 / 3.0$ & 2.7 & $2.7 / 6.5$ & $2.7 / 10$ & 10.5 & 3.8 & 10.0 & 10.0 & $3 ; 4.5$ \\
\hline $\mathrm{H}_{2} \mathrm{O}_{2}, \mathrm{~kg} / \mathrm{odt}$ & - & - & - & - & - & 3 & - & $1-5$ & 2 & 5 \\
\hline Mo, $\mathrm{kg} / \mathrm{odt}$ & - & - & - & - & - & - & - & - & - & $0.10-0.25$ \\
\hline $\mathrm{ClO}_{2}$ as $\mathrm{Cl}_{2}, \mathrm{~kg} / \mathrm{odt}$ & KF & KF & $\mathrm{KF}$ & $\mathrm{KF}$ & - & - & $10-45$ & - & - & - \\
\hline $\mathrm{O}_{3}, \mathrm{~kg} / \mathrm{odt}$ & - & - & - & - & $6 / 0$ & - & - & - & - & - \\
\hline DTPA, $\mathrm{kg} / \mathrm{odt}$ & - & - & - & $0 / 1.5$ & - & - & - & - & - & - \\
\hline
\end{tabular}

were obtained by multiplying chemical doses $(\mathrm{kg} / \mathrm{odt}$ pulp) by chemical prices (US\$/kg chemical). Relative bleaching chemical costs were derived by considering. the lowest chemical costs as 100 and whatever higher or lower number as a percentage over this value. The following chemical prices (US $\$ / \mathrm{kg}$ of product at $100 \%$ ) were used to calculate bleaching costs: $\mathrm{ClO}_{2}=1.00, \mathrm{H}_{2} \mathrm{O}_{2}$ $=0.85, \mathrm{O}_{2}=0.10, \mathrm{NaOH}=0.50, \mathrm{H}_{2} \mathrm{SO}_{4}=0.08, \mathrm{O}_{3}=1.80$, ammonium molybdate $=65.0, \mathrm{DTPA}=1.50$. Total active chlorine demands were calculated by multiplying the chemical consumptions (kg/odt) by the equivalent active chlorine contained in each one of the oxidants used in the bleaching sequence. The following conversion factors were used: $1 \mathrm{~kg} /$ odt $\mathrm{ClO}_{2}=2.63 \mathrm{~kg}$ active $\mathrm{Cl}_{2}, 1 \mathrm{~kg} / \mathrm{odt}$ $\mathrm{H}_{2} \mathrm{O}_{2}=2.09 \mathrm{~kg}$ active $\mathrm{Cl}_{2}$ and $1 \mathrm{~kg} / \mathrm{odt} \mathrm{O}_{3}=4.44 \mathrm{~kg}$ active $\mathrm{Cl}_{2}$.

After each bleaching stage of selected sequences filtrates were collected. The filtrates were mixed together and made into the combined effluent of the sequence. The mixed effluent was characterized for the chemical oxygen demand (COD), biochemical oxygen demand (BOD), adsorbable organic halogen (AOX) and color, according to standard procedures [11]. Effluent toxicity was determined using the short-term Daphnia similis acute toxicity assay, as described by the [12].

\section{Results and discussion}

\subsection{Optimization of the Molybdenum Activated Peroxide Stage (PMo)}

\subsubsection{Difficult-to-Bleach Pulp}

The kappa number results (Figure 1) show that both $\mathrm{PMo}$ and A/PMo stages delignification efficiency are slightly better at $\mathrm{pH} 3$ than at $\mathrm{pH} 4.5$. But, increasing molybdenum dose from 0.15 to $0.25 \mathrm{~kg} / \mathrm{odt}$ has little effect on efficiency. In fact, increasing the molybdenum dose at $\mathrm{pH} 4.5$ resulted in decreased delignification efficiency. Raising the PMo stage temperature form 85 to $95^{\circ} \mathrm{C}$ positively affected the efficiency. The A/PMo stage showed higher impact on pulp kappa number than the PMo one likely due to significant HexA removal in the $\mathrm{A} /$ part of the $\mathrm{A} / \mathrm{PMo}$ stage. The kappa number decrease with lowering $\mathrm{pH}$ and increasing temperature is explained by more efficient removal of pulp HexA under 


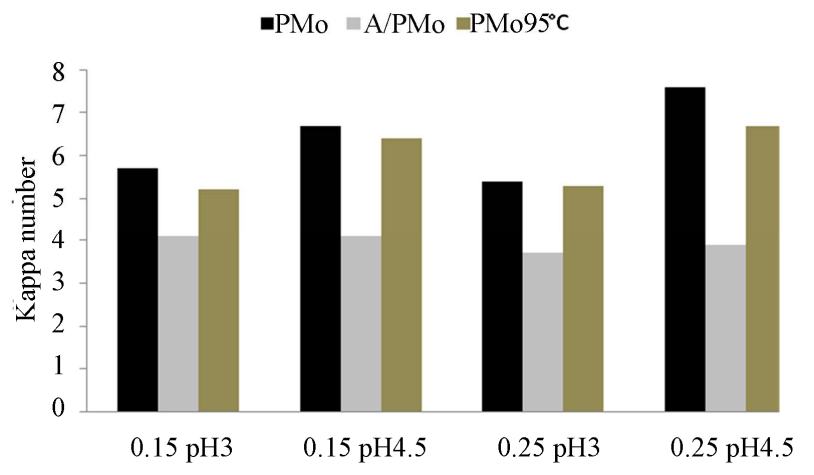

Figure 1. Influence of $\mathrm{pH}$ and molybdenum charge on difficult-to-bleach pulp kappa number after PMo $\left(85^{\circ} \mathrm{C}\right)$, A/PMo $\left(85^{\circ} \mathrm{C}\right)$ and PMo $\left(95^{\circ} \mathrm{C}\right)$ stages carried out at the following constant conditions: $5 \mathrm{~kg} / \mathrm{t} \mathrm{H}_{2} \mathrm{O}_{2}, 2 \mathrm{~h}$ and $10 \%$ consistency. Kappa in $=10.9$. In the $X$ axis, 0.15 pH 3 indicates reaction at $\mathrm{pH} 3$ with $0.15 \mathrm{kgMo} / \mathrm{odt}$ pulp. The same apply to the other acronyms.

these conditions. It is well known that a significant fraction of the kappa removal in the PMo stage is due to HexA elimination [7]. Since molybdenum functions as catalysts for the acid peroxide reaction, increasing dose above a certain limit has seemingly no effect on kappa number. However, the negative effect of molybdenum dose on delignification efficiency is of difficult explanation. Pulp viscosity (Figure 2) behaved similarly to kappa number, i.e., the lower the kappa number after the PMo or A/PMo stages the lower the viscosity. Highest viscosities were achieved with the PMo stage run at $85^{\circ} \mathrm{C}$ whereas lowest values were seen for the A/PMo stage. Brightness (Figure 3), on the other hand, showed a peculiar behavior. The highest values were measured on the pulps treated with the PMo stage run at $95^{\circ} \mathrm{C}$. In spite of its high delignification efficiency the A/PMo stage did not bleach the pulp accordingly. In fact, the brightness

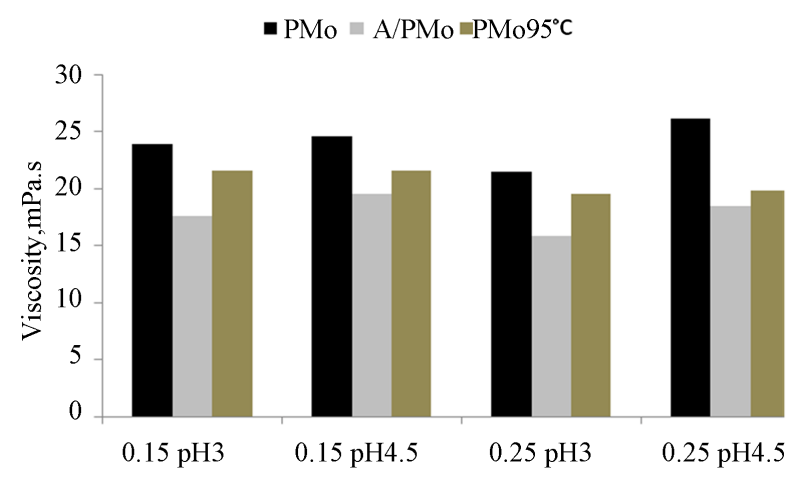

Figure 2. Influence of $\mathbf{p H}$ and molybdenum charge on difficult-to-bleach pulp viscosity after PMo $\left(85^{\circ} \mathrm{C}\right)$, A/PMo $\left(85^{\circ} \mathrm{C}\right)$ and PMo $\left(95^{\circ} \mathrm{C}\right)$ stages carried out at the following constant conditions: $5 \mathrm{~kg} / \mathrm{t} \mathrm{H}_{2} \mathrm{O}_{2}, 2 \mathrm{~h}$ and $10 \%$ consistency. Kappa in $=10.9$.

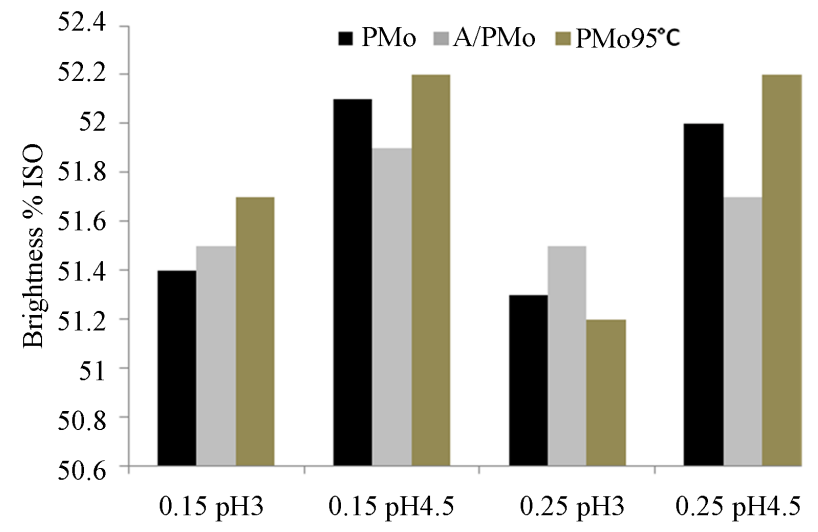

Figure 3. Influence of $\mathrm{pH}$ and molybdenum charge on difficult-to-bleach pulp brightness after PMo $\left(85^{\circ} \mathrm{C}\right), \mathrm{A} / \mathrm{PMo}$ $\left(85^{\circ} \mathrm{C}\right)$ and PMo $\left(95^{\circ} \mathrm{C}\right)$ stages carried out at the following constant conditions: $5 \mathrm{~kg} / \mathrm{t} \mathrm{H}_{2} \mathrm{O}_{2}, 2 \mathrm{~h}$ and $10 \%$ consistency. Kappa in $=10.9$.

after A/PMo stage was in several cases lower than that of the PMo stage run at $85^{\circ} \mathrm{C}$. Pulp darkening during the $\mathrm{A} /$ part of the A/PMo stage may explain the low brightness values.

The results previously discussed do not allow for a clear definition of the most appropriate condition to run the PMo and A/PMo stages. As far as delignification efficiency and brightness gains, the dose of $0.15 \mathrm{~kg}$ $\mathrm{Mo} / \mathrm{odt}$ pulp is certainly sufficient and the reaction at $\mathrm{pH}$ 3 at $95^{\circ} \mathrm{C}$ is more efficient. However, the opposite is observed for pulp viscosity. On the other hand, running the PMo stage at $95^{\circ} \mathrm{C}$ is more costly than at $85^{\circ} \mathrm{C}$, with the gains due to the high temperature being questionable.

\subsubsection{Easy-to-Bleach Pulp}

The results presented in Figure 4 corroborate those previously found for the difficult-to-bleach pulp (Figure 1) that better delignification efficiency is achieved at $\mathrm{pH} 3$ than at $\mathrm{pH} 4.5$. On the other hand, increasing molybdenum catalyst dose from 0.10 to $0.15 \mathrm{~kg} / \mathrm{odt}$ pulp has no significant impact on delignification efficiency but negatively affect viscosity, particularly for the A/PMo treatment (Figure 5). The values of brightness tended to be higher for the A/PMo than for the PMo treated pulp (Figure 6). The catalyst dose did not affect brightness substantially. Therefore, for the easy-to-bleach pulp sample, a molybdenum catalyst dose of $0.10 \mathrm{~kg} \mathrm{Mo} / \mathrm{odt}$ pulp should be sufficient. This result is in agreement with those of [7].

\subsection{Comparison of PMo and A/PMo Stages Performances on Difficult- and Easy-to-Bleach Pulps}

A comparison of the PMo and A/PMo stage perform- 


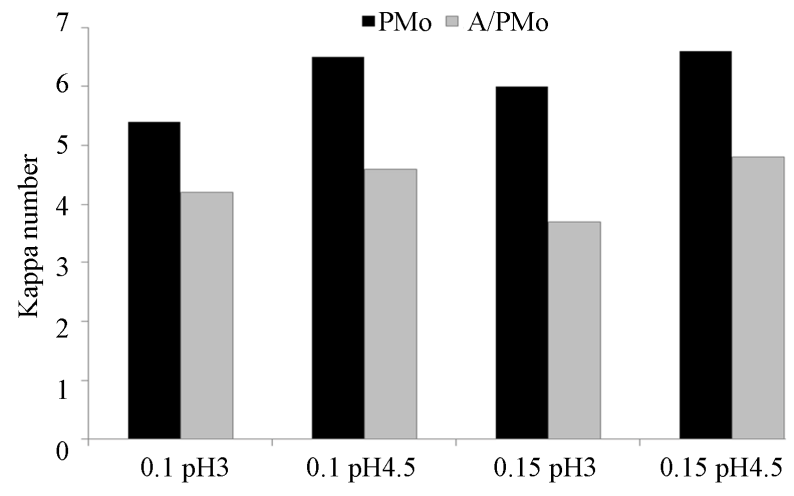

Figure 4. Influence of $\mathrm{pH}$ and molybdenum charge on easyto-bleach pulp kappa number after PMo, and A/PMo stages carried out at the following constant conditions: $5 \mathrm{~kg} / \mathrm{t} \mathrm{H}_{2} \mathrm{O}_{2}$, $85^{\circ} \mathrm{C}, 2 \mathrm{~h}$ and $10 \%$ consistency. Kappa in $=11.9$. In the $\mathrm{X}$ axis, $0.1 \mathrm{pH} 3$ indicates reaction at $\mathrm{pH} 3$ with $0.10 \mathrm{kgMo} / \mathrm{odt}$ pulp. The same apply to the other acronyms.

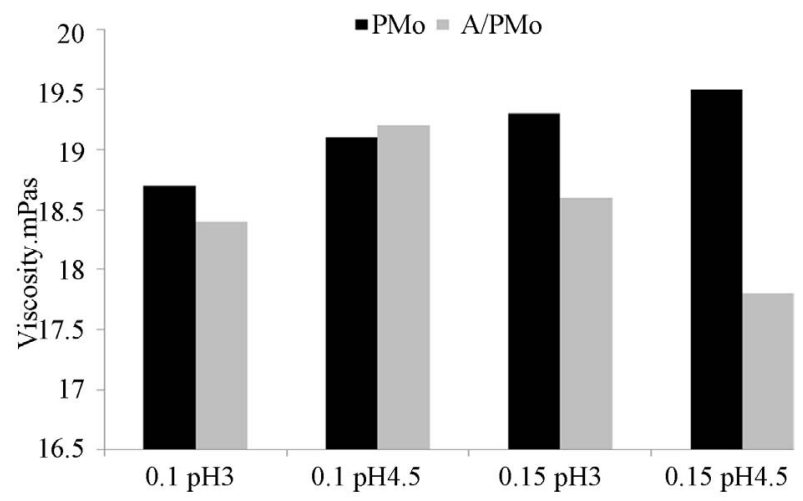

Figure 5. Influence of $\mathrm{pH}$ and molybdenum charge on easyto-bleach pulp viscosity after PMo, and A/PMo stages carried out at the following constant conditions: $5 \mathrm{~kg} / \mathrm{t} \mathrm{H}_{2} \mathrm{O}_{2}$, $85^{\circ} \mathrm{C}, 2 \mathrm{~h}$ and $10 \%$ consistency. Kappa in $=11.9$.

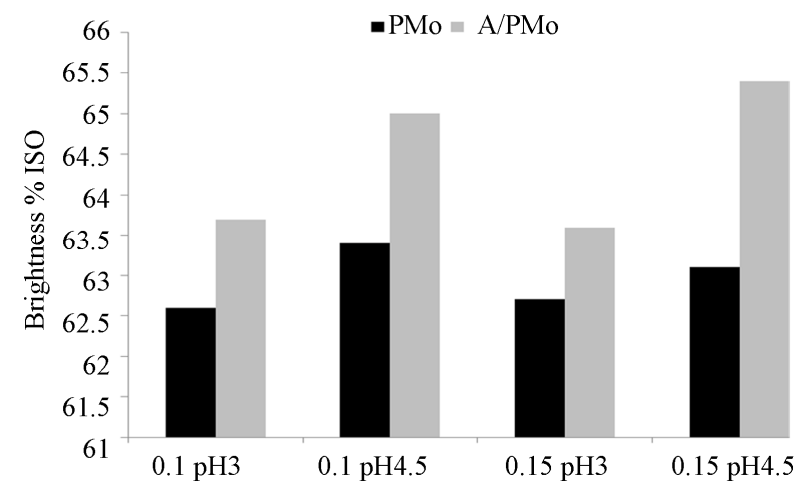

Figure 6. Influence of $\mathrm{pH}$ and molybdenum charge on easyto-bleach pulp brightness after PMo, and A/PMo stages carried out at the following constant conditions: $5 \mathrm{~kg} / \mathrm{t}_{2} \mathrm{O}_{2}$, $85^{\circ} \mathrm{C}, 2 \mathrm{~h}$ and $10 \%$ consistency. Kappa in $=11.9$. ances for the so-called difficult- and easy-to-bleach pulps, under similar operational conditions is shown in Table 3. Contrarily to the anticipated, it was observed that both PMo and A/PMo stage delignification efficiencies, as measured by the kappa drop and brightness gain across the stages, are higher for the difficult- than for the easy-to-bleach pulp sample. These results indicate that molybdenum activated peroxide stages are efficient to deal with lignin structures that are normally difficult to remove from pulps using conventional ECF bleaching. Note that the definition of difficult- and easy-to-bleach was based on the chemical requirements to bleach the pulp to $90 \%$ ISO with the D(EP)DP sequence.

\subsection{Bleaching Results}

\subsubsection{Difficult-to-Bleach Pulp}

The sequences evaluated for the difficult-to-bleach pulp included PMo(EP)DP, A/PMo(EP)DP, PMo/Q(PO) and $\mathrm{PMo}(\mathrm{PO}) \mathrm{D}$. References to these sequences included the $\mathrm{D}(\mathrm{EP}) \mathrm{DP}, \mathrm{D}_{\mathrm{HT}}(\mathrm{EP}) \mathrm{DP}, \mathrm{A} / \mathrm{D}(\mathrm{EP}) \mathrm{DP}$ and $\mathrm{D} / \mathrm{Q}(\mathrm{PO})$ ones. The results presented in Table 4 indicate that the target brightness of $90 \%$ ISO was achieved only with the sequences PMo(EP)DP and A/PMo(EP)DP. The total active chlorine demand and bleaching cost of the sequences containing the PMo and A/PMo stage are higher than their reference counterparts. On the other hand, their pulp brightness reversion and viscosity are lower than those of the references. The sequences $\mathrm{PMo} / \mathrm{Q}(\mathrm{PO})$ and Pmo(PO)D produced brightness in the range of $86-88 \%$ ISO at very high chemical doses. The $90 \%$ ISO brightness target could potentially have been achieved with these sequences, albeit at a very high cost. Among the reference bleaching processes, lowest bleaching costs were achieved with the $\mathrm{D}_{\mathrm{HT}}(\mathrm{EP}) \mathrm{DP}$ sequence.

\subsubsection{Easy-to-Bleach Pulp}

For the easy-to-bleach pulp, the following sequences were evaluated: $\mathrm{D}(\mathrm{EP}) \mathrm{DP}, \mathrm{D}_{\mathrm{HT}}(\mathrm{EP}) \mathrm{DP}, \mathrm{A} / \mathrm{D}(\mathrm{EP}) \mathrm{DP}$, Z/EDP, PMo(EP)DP, A/PMo(EP)DP and PMoZ/ED (Table 5). The sequences containing the PMo and A/PMo stages showed higher total active chlorine demand and relative chemical costs in relation to their reference counterparts. Overall the viscosities of the pulps treated with sequences containing PMo and A/PMo stages were lower. The sequences PMo(EP)DP and A/ $\mathrm{PMo}(\mathrm{EP}) \mathrm{DP}$ produced pulp of lower brightness reversion in relation to their references, but reversion was high when the PMo stage was applied in the PMoZ/ED sequence.

\subsubsection{Bleachability Comparison Between the Difficult- and Easy-to-Bleach Pulps}

Table 6 shows the total active chlorine demands and 
Table 3. Comparison of the PMo and A/PMo stage performance applied to difficult-and easy-tobleach pulp samples under similar operational conditions.

\begin{tabular}{lcccc}
\hline Parameter & \multicolumn{2}{c}{ Difficult-to-Bleach Pulp } & \multicolumn{2}{c}{ Easy-to-Bleach Pulp } \\
\hline Bleaching Stage & PMo* & A/PMo** & PMo* & A/PMo** \\
Brightness & 51.4 & 51.5 & 62.7 & 63.6 \\
Kappa Number & 5.7 & 4.1 & 6 & 3.7 \\
Viscosity, mPa.s & 23.9 & 17.6 & 19.5 & 18.6 \\
Brightness Gain, \% ISO & 7.1 & 7.2 & 5.4 & 6.3 \\
Kappa Drop (Efficiency), \% & 47.7 & 62.4 & 34.1 & 59.3 \\
Viscosity Drop, \% & 20.9 & 41.7 & 18.1 & 21.8 \\
\hline
\end{tabular}

*PMo fixed conditions: $10 \%$ consistency; 120 min.; $\mathrm{pH} 3.0 ; 0.15 \mathrm{~kg} \mathrm{Mo} / \mathrm{odt} ; 5 \mathrm{~kg} / \mathrm{odt} \mathrm{H}_{2} \mathrm{O}_{2} ; 85^{\circ} \mathrm{C}$.

**A/PMo fixed conditions: $11 / 10 \%$ consistency; $110 / 120$ min.; $\mathrm{pH} 3.0 ; 0.15 \mathrm{~kg} \mathrm{Mo} / \mathrm{odt} ; 5 \mathrm{~kg} / \mathrm{odt}_{2} \mathrm{O}_{2} ; 95 / 85^{\circ} \mathrm{C}$.

Table 4. Chemical consumptions, relative costs and pulp characterisitics for bleaching with the sequences $D(E P) D P$, $\mathrm{D}_{\mathrm{HT}}(\mathrm{EP}) \mathrm{DP}, \mathrm{A} / \mathrm{D}(\mathrm{EP}) \mathrm{DP}, \mathrm{D} / \mathrm{Q}(\mathrm{PO})$, Z/EDP, PMo(EP)DP, A/PMo(EP)DP, PMo/Q(PO), and PMo(PO)D.

\begin{tabular}{cccccc}
\hline SEQUENCE & $\begin{array}{c}\text { Brightness, } \\
\text { \% ISO }\end{array}$ & $\begin{array}{c}\text { Reversion, } \\
\text { \% ISO }\end{array}$ & $\begin{array}{c}\text { Viscosity, } \\
\text { mPa.s }\end{array}$ & $\begin{array}{c}\text { Relative } \\
\text { Chemical Cost }\end{array}$ & $\begin{array}{c}\text { Total Active Chlorine } \\
\text { Demand, kg/odt pulp }\end{array}$ \\
\hline (EP)DP & 90.0 & 1.3 & 18.3 & 133 & 42.9 \\
D HT(EP)DP $^{\text {PMo(EP)DP }}$ & 90.3 & 1.5 & 15.4 & 119 & 37.6 \\
A/D(EP)DP & 90.7 & 1.2 & 14 & 212 & 50.8 \\
A/PMo(EP)DP* & 89.8 & 1.8 & 17.6 & 140 & 42.9 \\
D/Q(PO) & 90.6 & 1.1 & 12.1 & 201 & 47.2 \\
PMo/Q(PO) & 90.3 & 1.9 & 21.1 & 221 & 73.4 \\
Z/EDP & 86.3 & 1.3 & 13.0 & 369 & 115 \\
PMo(PO)D $^{*}$ & 90.3 & 1.3 & 14.2 & 166 & 43.7 \\
\hline
\end{tabular}

*PMo fixed conditions: $10 \%$ consistency; 120 min.; pH 3.0; $0.15 \mathrm{~kg} \mathrm{Mo} / \mathrm{odt} ; 5 \mathrm{~kg} / \mathrm{odt} \quad \mathrm{H}_{2} \mathrm{O}_{2} ; 85^{\circ} \mathrm{C}$.

**A/PMo fixed conditions: 11/10\% consistency; $110 / 120$ min.; $\mathrm{pH} 3.0 ; 0.15 \mathrm{~kg} \mathrm{Mo} / \mathrm{odt} ; 5 \mathrm{~kg} / \mathrm{odt} \quad \mathrm{H}_{2} \mathrm{O}_{2} ; 95 / 85^{\circ} \mathrm{C}$.

Table 5. Chemical consumptions, relative costs and pulp characterisitics for bleaching with the sequences $D(E P) D P$, $\mathrm{D}_{\mathrm{HT}}(\mathrm{EP}) \mathrm{DP}$, A/D(EP)DP, Z/EDP, PMo(EP)DP, A/PMo(EP)DP and PMoZ/ED.

\begin{tabular}{|c|c|c|c|c|c|}
\hline SEQUENCE & $\begin{array}{c}\text { Brightness, } \\
\text { \% ISO }\end{array}$ & Reversion, \% ISO & Viscosity, mPa.s & $\begin{array}{c}\text { Relative } \\
\text { Chemical Cost }\end{array}$ & $\begin{array}{c}\text { Total Active Chlorine De- } \\
\text { mand, kg/odt pulp }\end{array}$ \\
\hline $\mathrm{D}(\mathrm{EP}) \mathrm{DP}$ & 90.5 & 1.6 & 16.6 & 109 & 32.9 \\
\hline $\mathrm{D}_{\mathrm{HT}}(\mathrm{EP}) \mathrm{DP}$ & 90.7 & 1.5 & 15.8 & 100 & 27.9 \\
\hline $\mathrm{PMo}(\mathrm{EP}) \mathrm{DP}^{*}$ & 90.0 & 1.2 & 16.3 & 185 & 40.9 \\
\hline $\mathrm{A} / \mathrm{D}(\mathrm{EP}) \mathrm{DP}$ & 89.8 & 1.9 & 15.8 & 107 & 27.9 \\
\hline $\mathrm{A} / \mathrm{PMo}(\mathrm{EP}) \mathrm{DP}^{* *}$ & 90.0 & 1.7 & 14.4 & 185 & 38.8 \\
\hline Z/EDP & 90.0 & 1.2 & 15.0 & 125 & 29.1 \\
\hline $\mathrm{PMoZ} / \mathrm{ED}^{*}$ & 90.2 & 3.2 & 12.4 & 166 & 31.0 \\
\hline
\end{tabular}

*PMo fixed conditions: $10 \%$ consistency; 120 min.; $\mathrm{pH} 3.0 ; 0.15 \mathrm{~kg} \mathrm{Mo} / \mathrm{odt} ; 5 \mathrm{~kg} / \mathrm{odt}_{2} \mathrm{O}_{2} ; 85^{\circ} \mathrm{C}$.

**A/PMo fixed conditions: $11 / 10 \%$ consistency; $110 / 120$ min.; $\mathrm{pH} 3.0 ; 0.15 \mathrm{~kg} \mathrm{Mo} / \mathrm{odt} ; 5 \mathrm{~kg} / \mathrm{odt}_{2} \mathrm{O}_{2} ; 95 / 85^{\circ} \mathrm{C}$.

relative bleaching chemical costs for selected sequences applied to the difficult and easy-to-bleach pulps. Reference sequences as well as those containing PMo and A/PMo stages are presented. The values clearly indicate that the easy-to-bleach pulp respond significantly better to the selected bleaching sequences than the difficult-to-bleach one. Since the two pulps behaved inversely than expected in the PMo and A/PMo stages alone (Table 3), it is concluded that the significant difference in bleachability between the difficult-and easy- 
Table 6. Bleachabilities of difficult- and easy-to-bleach pulps with D(EP)DP, $\mathrm{D}_{\mathrm{HT}}$ (EP)DP, A/D(EP)DP, Z/EDP, PMo(EP)DP and A/PMo(EP)DP sequences.

\begin{tabular}{|c|c|c|c|c|}
\hline \multirow[b]{2}{*}{ SEQUENCE } & \multicolumn{2}{|c|}{ Difficult-to-Bleach Pulp } & \multicolumn{2}{|c|}{ Easy-to-Bleach Pulp } \\
\hline & Relative Chemical Cost & $\begin{array}{l}\text { Total Active Chlorine } \\
\text { Demand, kg/odt pulp }\end{array}$ & $\begin{array}{c}\text { Relative } \\
\text { Chemical Cost }\end{array}$ & $\begin{array}{l}\text { Total Active Chlorine } \\
\text { Demand, kg/odt pulp }\end{array}$ \\
\hline $\mathrm{D}(\mathrm{EP}) \mathrm{DP}$ & 133 & 42.9 & 109 & 32.9 \\
\hline $\mathrm{D}_{\mathrm{HT}}(\mathrm{EP}) \mathrm{DP}$ & 119 & 37.6 & 100 & 27.9 \\
\hline $\mathrm{A} / \mathrm{D}(\mathrm{EP}) \mathrm{DP}$ & 140 & 42.9 & 107 & 27.9 \\
\hline $\mathrm{Z} / \mathrm{EDP}$ & 166 & 43.7 & 125 & 29.1 \\
\hline PMo(EP)DP* & 212 & 50.8 & 185 & 40.9 \\
\hline $\mathrm{A} / \mathrm{PMo}(\mathrm{EP}) \mathrm{DP}^{* *}$ & 201 & 47.2 & 185 & 38.8 \\
\hline
\end{tabular}

*PMo fixed conditions: $10 \%$ consistency; 120 min.; $\mathrm{pH} 3.0 ; 0.15 \mathrm{~kg} \mathrm{Mo} / \mathrm{odt} ; 5 \mathrm{~kg} / \mathrm{odt} \mathrm{H}_{2} \mathrm{O}_{2} ; 85^{\circ} \mathrm{C}$.

**A/PMo fixed conditions: $11 / 10 \%$ consistency; $110 / 120$ min.; $\mathrm{pH} 3.0 ; 0.15 \mathrm{~kg} \mathrm{Mo} / \mathrm{odt} ; 5 \mathrm{~kg} / \mathrm{odt} \mathrm{H}_{2} \mathrm{O}_{2} ; 95 / 85^{\circ} \mathrm{C}$.

to-bleach pulps is in fact due to differences in their reactivity towards chlorine dioxide bleaching.

\subsection{Refinability and Physical Properties of Easy-to-Bleach Pulp Sample}

Considering the results discussed in the previous session, the A/PMo(EP)DP, PMo(EP)DP and $\mathrm{D}_{\mathrm{HT}}$ (EP)DP (reference) sequences were selected to produce pulp for refinability and physical property evaluations. Only the easy-to-bleach pulp sample was investigated. For the drainage degrees of interest (20 and $35^{\circ} \mathrm{SR}$ ), no significant differences in refinability between the pulps bleached with the $\mathrm{D}_{\mathrm{HT}}(\mathrm{EP}) \mathrm{DP}$ and PMo(EP)DP sequences were seen. On the other hand, the pulp bleached with the $\mathrm{A} / \mathrm{PMo}(\mathrm{EP}) \mathrm{DP}$ sequence was more difficult to refine since it required more energy $(\sim 20 \%)$ to achieve a given drainage degree (Figure 7). The latter sequence contains a hot acid hydrolysis stage which may have dissolved some of the pulp hemicelluloses during bleaching and that negatively affected refinability.

Eucalyptus pulps are usually commercialized for printing \& writing ( $\mathrm{P} \& \mathrm{~W}$ ) and tissue paper grades. These two types of products require different levels of refining, with the tissue grade pulps requiring very low beating $\left(20-25^{\circ} \mathrm{SR}\right)$. On the other hand, the drainage degree required for manufacturing $\mathrm{P} \& \mathrm{~W}$ paper grades is usually in the range of $30-40^{\circ} \mathrm{SR}$. Thus the 20 and $35^{\circ} \mathrm{SR}$ values were selected for property evaluations aimed at tissue and $\mathrm{P} \& \mathrm{~W}$ paper grades.

The results presented in Table 7 show that in regard to tensile related properties, including tensile index, tensile energy adsorption, modulus of elasticity and stretch there were no significant differences among the three bleached pulps both for tissue and printing and writing paper grades, indicating no effect of the PMo stage. At lower beating degree (tissue grade pulps) the tear index tended to be about $10 \%$ lower for the pulps bleached with the sequences containing the PMo stage. With more beating (P\&W grade pulp) the PMo(EP)DP pulp recovered the tear strength showing values similar to the that of the reference pulp but the pulp bleached with the A/PMo(EP)DP sequence still presented a 10\% lower tear index at $35^{\circ} \mathrm{SR}$. The lower tear strength of the pulp bleached with the A/PMo(EP)DP sequence is in line with its low viscosity at the end of bleaching. The A/PMo(EP)DP sequence produced pulp of significantly higher air resistance in relation to the reference at the high $35^{\circ} \mathrm{SR}$ but significantly lower at $20^{\circ} \mathrm{SR}$. This result is explained by the potential of this pulp to form fines during beating due to its lower integrity (low viscosity). The PMo(EP)DP bleached pulp did not show this trend. Although its air resistance was lower than that of the reference at $20^{\circ} \mathrm{SR}$, it did not increase so much with prolonged beating, indicating better fiber integrity. No significant differences were observed in bulk among the various pulps both at 20 and $35^{\circ} \mathrm{SR}$.

\subsection{Effluent Load and Treatability of Easy-to-Bleach Pulp}

On the basis of the results discussed in the previous ses-

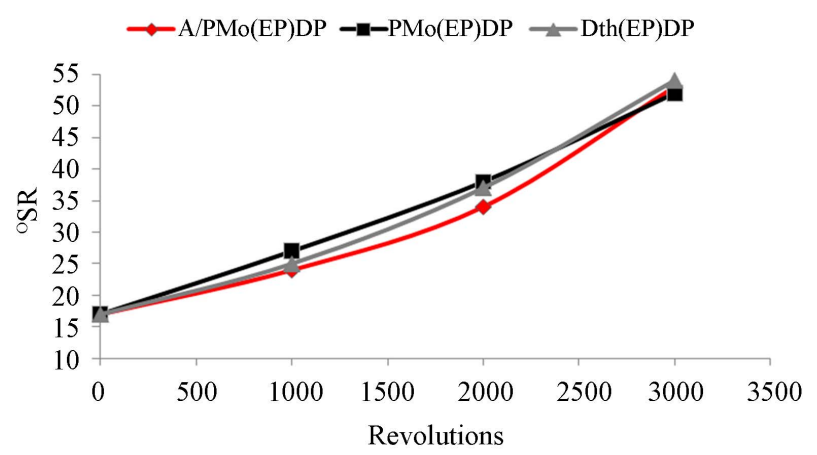

Figure 7. Refinability curves of pulp samples bleached by different procedures. 
Table 7. Refinability and physical properties of pulps bleached with $\mathrm{D}_{\mathrm{HT}}(\mathrm{EP}) \mathrm{DP}, \mathrm{A} / \mathrm{PMo}(\mathrm{EP}) \mathrm{DP}$ and PMo(EP)DP sequences.

\begin{tabular}{|c|c|c|c|c|c|c|}
\hline \multirow{2}{*}{$\begin{array}{c}\text { Bleaching Process } \\
\text { Product }\end{array}$} & \multicolumn{2}{|c|}{$\mathbf{D}_{\mathrm{HT}}(\mathrm{EP}) \mathrm{DP}$} & \multicolumn{2}{|c|}{ A/PMo(EP)DP } & \multicolumn{2}{|c|}{ PMo(EP)DP } \\
\hline & Tissue & $\mathbf{P} \& \mathbf{W}$ & Tissue & $\mathbf{P} \& \mathbf{W}$ & Tissue & $\mathbf{P} \& \mathbf{W}$ \\
\hline Drainage Degree, ${ }^{\circ} \mathrm{SR}$ & 20.0 & 35.0 & 20.0 & 35.0 & 20.0 & 35.0 \\
\hline PFI Revolutions & 544 & 1880 & 682 & 2105 & 431 & 1739 \\
\hline Energy consumption, $\mathrm{W} \cdot \mathrm{h}$ & 8.6 & 19.5 & 8.9 & 25.4 & 8.5 & 19.5 \\
\hline Sheet Density, $\mathrm{g} / \mathrm{cm}^{3}$ & 0.584 & 0.710 & 0.576 & 0.733 & 0.583 & 0.693 \\
\hline Bulk, $\mathrm{cm}^{3} / \mathrm{g}$ & 1.71 & 1.41 & 1.74 & 1.36 & 1.71 & 1.44 \\
\hline T.E.A., $\mathrm{J} / \mathrm{m}^{2}$ & 78 & 134 & 86 & 129 & 87 & 121 \\
\hline Modulus of Elasticity, $\mathrm{MN} \cdot \mathrm{m} / \mathrm{kg}$ & 4.3 & 6.1 & 4.5 & 6.4 & 4.9 & 6.1 \\
\hline Tensile Index, $\mathrm{N} \cdot \mathrm{m} / \mathrm{g}$ & 49.8 & 75.4 & 48.8 & 75.7 & 48.6 & 73.7 \\
\hline Burst index, $\mathrm{kPa} \cdot \mathrm{m}^{2} / \mathrm{g}$ & 2.0 & 4.0 & 2.0 & 4.3 & 2.1 & 4.1 \\
\hline Tear Index, $\mathrm{mN} \cdot \mathrm{m}^{2} / \mathrm{g}$ & 8.6 & 10.2 & 7.7 & 9.3 & 7.5 & 10.1 \\
\hline Stretch, \% & 3.1 & 4.1 & 2.9 & 3.9 & 3.2 & 3.8 \\
\hline Opacity, \% & 76.7 & 72.9 & 77.6 & 72.2 & 77.3 & 72.1 \\
\hline Air Resistance, $\mathrm{s} / 100 \mathrm{~cm}^{3}$ & 4.1 & 15.3 & 2.7 & 27.5 & 2.5 & 12.5 \\
\hline
\end{tabular}

sion, the $\mathrm{A} / \mathrm{PMo}(\mathrm{EP}) \mathrm{DP}, \mathrm{PMo}(\mathrm{EP}) \mathrm{DP}$ and $\mathrm{D}_{\mathrm{HT}}(\mathrm{EP}) \mathrm{DP}$ (reference) sequences were selected to produce effluent for load and treatability evaluations. Only the easyto-bleach pulp sample was investigated. Combined effluent samples were prepared by mixing equal amounts of filtrates from each bleaching stage of the sequence.

Characterization of the raw effluents, expressed as both concentration $(\mathrm{mg} / \mathrm{L})$ and load $(\mathrm{kg} / \mathrm{odt})$ is presented in Table 8. In general, incorporation of the molybdenum catalyzed acid peroxide stage improved raw effluent quality and resulted in lower effluent pollutant loads. Although COD loads were similar for all three effluents, the BOD load of the PMo(EP)DP sequence was much lower than that of the $\mathrm{D}_{\mathrm{HT}}(\mathrm{EP}) \mathrm{DP}$ and $\mathrm{A} / \mathrm{PMo}(\mathrm{EP}) \mathrm{DP}$ sequences. Therefore, the $\mathrm{BOD} / \mathrm{COD}$ relationship, typically used to express effluent biodegradability and applicability of biological treatment processes, was lowest for the PMo(EP)DP effluent (0.29), indicating that the organic matter in this effluent was in a less readily biodegradable form than that dissolved in the other bleaching effluents evaluated.

Not surprisingly, the highest effluent AOX values were found in the $\mathrm{D}_{\mathrm{HT}}(\mathrm{EP}) \mathrm{DP}$ effluent, because of the use of chlorine dioxide in the first bleaching stage. Incorporation of the molybdenum catalyzed acid peroxide stage eliminates the possibility of formation of organochlorine compounds during the initial bleaching stages. It should be noted, however, that AOX formation is very low, even when the $\mathrm{D}_{\text {Hт }}$ stage was used.

Effluent color was greatly reduced by the use of the molybdenum catalyzed acid peroxide stage instead of the hot chlorine dioxide stage. The beneficial effect on effluent color was greatest when the peroxide stage was preceded by a hot acid stage (A/PMo).

None of the effluents evaluated exhibited acute toxicity to Daphnia similis, indicating that molybdenum used as catalyst was not dissolved in the effluents in toxic levels. Given the absence of toxicity in the raw effluents, toxicity was not evaluated in treated effluents, since it is generally accepted that biological treatment is capable of eliminating acute toxicity from bleaching effluents [13].

Biological treatment stability is presented in Figure 8. Treated effluent COD values rapidly stabilized and remained relatively constant after ten treatment cycles in the SBRs. Based on these results, more detailed effluent characterization was initiated on day 19 , and continued until day 24. Results of the final effluent characterization are presented in Table 9. Average removal efficiencies over the course of the effluent characterization are presented in Table 10.

Final effluent quality measured as BOD and COD was not statistically different for the three effluents, while lower final effluent color and AOX were obtained in the effluents that incorporated the molybdenum catalyzed acid peroxide stage. The low biodegradability $(\mathrm{BOD} / \mathrm{C}-$ OD ratio) in the raw $\mathrm{PMo}(\mathrm{EP}) \mathrm{DP}$ effluent was confirmed 
Table 8. Characterization of raw effluents.

\begin{tabular}{llccc}
\hline Parameter & Units & $\mathbf{D}_{\text {HT }}$ EP)DP & $\begin{array}{c}\text { Effluent } \\
\text { PMo(EP)DP }\end{array}$ & A/PMo(EP)DP \\
\hline COD & $\mathrm{mg} \cdot \mathrm{l}^{-1}$ & 880 & 834 & 842 \\
& $\mathrm{~kg} \cdot \mathrm{odt}^{-1}$ & 31.7 & 30.0 & 29.6 \\
$\mathrm{BOD}$ & $\mathrm{mg} \cdot \mathrm{l}^{-1}$ & 425 & 246 & 383 \\
& $\mathrm{~kg} \cdot \mathrm{odt}^{-1}$ & 15.3 & 8.9 & 13.4 \\
$\mathrm{BOD} / \mathrm{COD}$ & - & 0.48 & 0.29 & 0.45 \\
Color & $\mathrm{mg} \cdot \mathrm{l}^{-1}$ & 270 & 195 & 148 \\
& $\mathrm{~kg} \cdot \mathrm{odt}^{-1}$ & 9.7 & 7.0 & 5.2 \\
AOX & $\mathrm{mg} \cdot \mathrm{l}^{-1}$ & 4 & 1.1 & 0.6 \\
& $\mathrm{~kg} \cdot \mathrm{odt}^{-1}$ & 0.14 & 0.04 & 0.02 \\
Acute toxicity & $\%$ & $>100$ & $>100$ & $>100$ \\
\hline
\end{tabular}

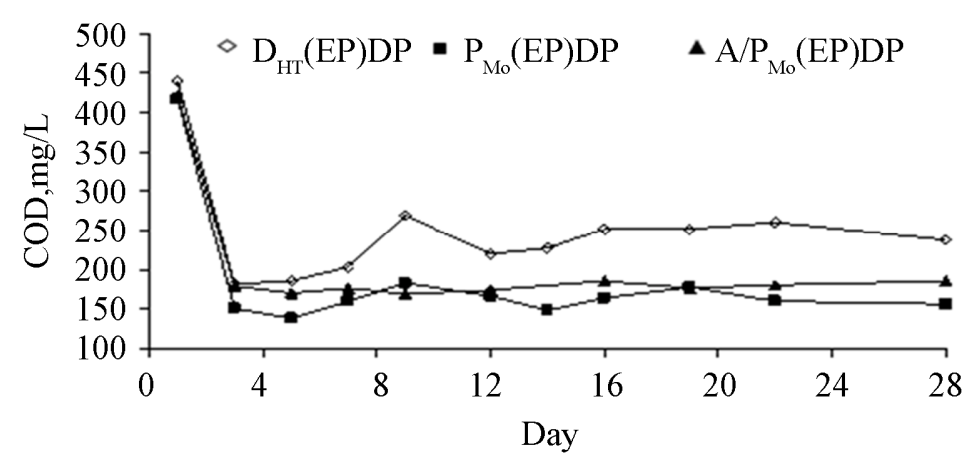

Figure 8. COD of biologically treated bleaching effluents.

Table 9. Biologically treated bleaching effluent characteristics.

\begin{tabular}{|c|c|c|c|c|}
\hline \multirow{2}{*}{ Parameter } & \multirow{2}{*}{ Units } & \multicolumn{3}{|c|}{ Effluent* } \\
\hline & & $\mathbf{D}_{\mathrm{HT}}(\mathrm{EP}) \mathrm{DP}$ & PMo(EP)DP & A/PMo(EP)DP \\
\hline \multirow{2}{*}{ COD } & $\mathrm{mg} \mathrm{L}^{-1}$ & $240^{\mathrm{a}}$ & $164^{a}$ & $178^{\mathrm{a}}$ \\
\hline & $\mathrm{kg} \mathrm{odt}^{-1}$ & 8.6 & 5.9 & 6.2 \\
\hline \multirow{2}{*}{ BOD } & $\mathrm{mg} \mathrm{L}^{-1}$ & $115^{\mathrm{a}}$ & $112^{\mathrm{a}}$ & $107^{\mathrm{a}}$ \\
\hline & $\mathrm{kg} \mathrm{odt}^{-1}$ & 4.1 & 4.0 & 3.8 \\
\hline \multirow[b]{2}{*}{ Color } & $\mathrm{mg} \mathrm{L}^{-1}$ & $304^{\mathrm{c}}$ & $180^{\mathrm{b}}$ & $154^{\mathrm{a}}$ \\
\hline & $\mathrm{kg}$ odt $^{-1}$ & 10.9 & 6.5 & 5.4 \\
\hline \multirow{2}{*}{ AOX } & $\mathrm{mg} \mathrm{L}^{-1}$ & $1.7^{\mathrm{b}}$ & $0.7^{\mathrm{a}}$ & $0.7^{\mathrm{a}}$ \\
\hline & $\mathrm{kg} \mathrm{odt}^{-1}$ & 0.061 & 0.025 & 0.024 \\
\hline
\end{tabular}

*Values in each row followed by the same letter are not statistically different, at a $5 \%$ level of significance.

Table 10. Biological treatment efficiency of bleaching effluents.

\begin{tabular}{lrrr}
\hline Parameter & \multicolumn{2}{c}{$\begin{array}{c}\text { Removal efficiency, } \% \\
\text { PMo(EP)DP }\end{array}$} & A/PMo(EP)DP \\
\hline COD & D HT $_{\text {HTP)DP }}$ & 80.3 & 78.9 \\
BOD & 72.7 & 54.5 & 72.1 \\
Color & 72.9 & 7.7 & -4.1 \\
AOX & -12.6 & 36.4 & -16.7 \\
\hline
\end{tabular}

by the low BOD removal efficiency of this effluent $(54.5 \%)$ as compared to the other two effluents evaluated $(>72 \%)$.

Biological treatment of the $\mathrm{D}_{\mathrm{HT}}(\mathrm{EP}) \mathrm{DP}$ and $\mathrm{A} / \mathrm{P}-$ Mo(EP)DP effluents led to increased effluent color (ne- gative removal efficiencies) and only marginal color removal in the PMo(EP)DP effluent. Increase in effluent color commonly occurs during biological treatment and indicates formation of new chromophores through partial oxidation of dissolved organic matter [13]. 
The hot acid stage (A/PMo) had a negative impact on AOX removal. The negative removal efficiency listed in Table 10 for the A/PMo(EP)DP effluent indicates no removal of organochlorine compounds from this effluent. This probably arose from the fact that the initial AOX level was very low $\left(6 \mathrm{mg} \mathrm{L}^{-1}\right)$, and was apparently comprised of only non-biodegradable (recalcitrant) compounds, similar to those formed in the $\mathrm{PMo}(\mathrm{EP}) \mathrm{DP}$ effluent, since final AOX values in these two effluents was virtually the same $\left(7 \mathrm{mg} \mathrm{L}^{-1}\right)$.

\section{Conclusions}

1) Optimal conditions to run the PMo stage include: $0.10-0.15 \mathrm{~kg} / \mathrm{t} \mathrm{Mo}, \mathrm{pH} 3$ and temperature $85-95^{\circ} \mathrm{C}$.

2) At a price of US $\$ 65 / \mathrm{kg}$ for the molybdenum salt, the PMo stage is not economically attractive.

3) The $\mathrm{A} / \mathrm{PMo}(\mathrm{EP}) \mathrm{DP}$ sequence is the most cost effective among the ones with PMo stage.

4) The pulp bleached with the A/PMo(EP)DP sequence showed poorer refinability and tearing strength than the reference $\left(\mathrm{D}_{\mathrm{HT}}(\mathrm{EP}) \mathrm{DP}\right)$ while the $\mathrm{PMo}(\mathrm{EP}) \mathrm{DP}$ sequence was similar to the reference.

5) Untreated effluents from the $\mathrm{A} / \mathrm{PMo}(\mathrm{EP}) \mathrm{DP}$ and $\mathrm{PMo}(\mathrm{EP}) \mathrm{DP}$ sequences presented similar COD, but lower AOX than that from the $\mathrm{D}_{\mathrm{HT}}(\mathrm{EP}) \mathrm{DP}$ sequence. None of the effluents exhibited toxicity.

6) The untreated effluent from the A/PMo(EP)DP sequence showed lower $\mathrm{BOD}$ and $\mathrm{BOD} / \mathrm{COD}$ ratio in relation to that from the $\mathrm{PMo}(\mathrm{EP}) \mathrm{DP}$ sequence.

7) The effluents from $\mathrm{A} / \mathrm{PMo}(\mathrm{EP}) \mathrm{DP}, \mathrm{PMo}(\mathrm{EP}) \mathrm{DP}$ and $\mathrm{D}_{\mathrm{HT}}(\mathrm{EP}) \mathrm{DP}$ sequences were readily treated in the bench-scale reactors, and achieved COD removal efficiencies of greater than $70 \%$.

\section{REFERENCES}

[1] M. S. Rabelo, J. L. Colodette, V. M. Sacon, M. R. Silva and M. A. B. Azevedo, "Molybdenum Catalyzed Acid Perocixide Bleaching of Eucalyptus Kraft Pulp," BioResources, Vol. 3, No. 3, 2008, pp. 881-897.

[2] L. Colodette, M. C. Gomes, A. H. Mounteer and K. M. M. Eiras, "Modern High Brightness Low Impact Bleaching of Eucalyptus Kraft Pulp," IPW Das Papier, Vol. 1, 2006, pp. 14-17.

[3] H. Hämäläinen, A. Parén, J. Jäkära, T. Fant, "Mill-Scale Application of a Molybdate Activated Peroxide Delignification Process in ECF and TCF Production of Soft- wood and Hardwood Kraft Pulps" Proceedings of 12th ISWPC, Madison, Wisconsin, 2003, pp. 81-84.

[4] E. Begnor-Gidnert, P. E. Tomani and O. Dahlman, "Influence on Pulp Quality of Conditions during the Removal of Hexenuronic Acids," Nordic Pulp and Paper Research Journal, Vol. 13, No. 4, 1998, pp. 310-316. doi:10.3183/NPPRJ-1998-13-04-p310-316

[5] V. Kubelka, R. C. Francis and C. W. Dence, "Delignification with Acidic Hydrogen Peroxide Activated by Molybdate," Journal of Pulp Paper Science, Vol. 18, 1992, pp. 108-114.

[6] R. C. Eckert, "Delignification and Bleaching Process and Solution for Lignocellulosic Pulp with Peroxide in the Presence of Metal Additives," Canadian Patent 1129161, 1982.

[7] G. I. J. Sundman, "Molybdenum - and Tungsten - Catalyzed Reactions of Acid Hydrogen Peroxide with Kraft Lignin Model Compounds and Enzymatically-Liberated Kraft Lignin," Ph.D. Thesis, SUNY College of Environmental Science and Forestry, Syracuse, New York, 1988.

[8] F. R. Milagres, M. S. Rabelo, F. J. B. Gomes and J. L. Colodette, "Branqueamento de Polpa de Eucalipto com Seqüências Curtas," Proceeding 3rd ICEP - International Colloquium on Eucalyptus Pulp, Belo Horizonte, 2007, pp. 1-5.

[9] R. G. McDonald, "Pulp Kraft,” In: R. G. McDonald, Ed., Pulp \& Paper Manufacture, 2nd Edition, Vol. 1. McGraw-Hill Book Company, New York, 1967, pp. 628725.

[10] T. Vuorinen, J. Buchert, A. Teleman, M. Tenkanen and P. Fagerstrom, "Selective Hydrolysis of Hexenuronic Acid Groups," Journal Pulp Paper Science, Vol. 25, 1999, 155-162.

[11] APHA-American Public Health Association, Water Environment Federation, American Water Works Association, "Standard Methods for the Examination of Water and Wastewater", 20 Edition, APHA, WEF, AWWA, Washington, 1998.

[12] EPA-United States Environmental Protection Agency, "Methods for Measuring the Acute Toxicity of Effluents and Receiving Waters to Freshwater and Marine Organisms," 5th Edition, EPA-821-R-02-012, Washington, 2002.

[13] A. M. Springer, "Industrial Environmental Control," Pulp and Paper Industry, 2nd Edition, TAPPI PRESS, Atlanta, 1998. 